\title{
CYTOPROTECTIVE ACTIVITY OF ETHANOL FRACTION OF COLEUS AMBOINICUS LOUR. LEAVES AGAINST VERO CELLS INDUCED BY $\mathrm{H}_{2} \mathrm{O}_{2}$
}

\author{
RENY HARYANI ${ }^{1}$, URIP HARAHAP ${ }^{1 *}$, MASFRIA ${ }^{2}$, DENNY SATRIA ${ }^{3}$ \\ ${ }^{1}$ Departement of Pharmacology, Faculty of Pharmacy, Universitas Sumatera Utara, Medan, Indonesia. ${ }^{2}$ Departement of Pharmaceutical \\ Chemistry, Faculty of Pharmacy, Universitas Sumatera Utara, Medan, Indonesia. ${ }^{3}$ Departement of Pharmaceutical Biology, Faculty of \\ Pharmacy, Universitas Sumatera Utara, Medan, Indonesia. Email: urip.hrp@gmail.com
}

Received: 07 March 2018, Revised and Accepted:25 March 2018

ABSTRACT

Objective: The objective of this study is to assess the cytoprotective activity of Coleus amboinicus Lour. leaves ethanol fraction (EtF) in Vero cells which induced by hydrogen peroxide $\left(\mathrm{H}_{2} \mathrm{O}_{2}\right)$.

Methods: Cytoprotective activity was determined using 3-(4,5-dimethylthiazol-2)-2,5-diphenyltetrazolium bromide (MTT) method, apoptosis activity was analyzed by flow cytometry, and expression of radical spesies oxygen (ROS) was observed by imunocytochemistry.

Result: The EtF $(100 \mu \mathrm{g} / \mathrm{mL})$ was showed the highest percent viability $74.42 \pm 0.28 \%$ using MTT method. Furthermore, the EtF was increased viability of Vero cell after induced with $0.8 \mathrm{mM} \mathrm{H}_{2} \mathrm{O}_{2}$ and EtF was decreased the expression of ROS.

Conclusion: Based on the description, EtF has cytoprotective activity towards Vero cells which induced by $0.8 \mathrm{mM} \mathrm{H}_{2} \mathrm{O}_{2}$

Keywords: Cytoprotective activity, Coleus amboinicus Lour., Ethanol Fraction, $\mathrm{H}_{2} \mathrm{O}_{2}$, Vero cells.

(C) 2018 The Authors. Published by Innovare Academic Sciences Pvt Ltd. This is an open access article under the CC BY license (http://creativecommons. org/licenses/by/4. 0/) DOI: http://dx.doi.org/10.22159/ajpcr.2018.v11s1.26559

\section{INTRODUCTION}

Oxidative stress arises due to an imbalance between the production of free radicals or reactive oxygen species (ROS) and antioxidants, so free radical levels are higher than antioxidants [1]. Excessive ROS damages cellular lipids, proteins, and DNA and inhibits the normal function of cells [2]. Oxygen free radicals are formed as by-products of aerobic cellular metabolism and are produced under the conditions of oxidative stress. However, increased production of ROS which are unable to be neutralized by antioxidants in cells (such as superoxide dismutase and catalase) and lead to oxidative stress may disrupt cellular homeostasis and impair cell components including membrane lipids, proteins, and DNA [3].

Antioxidants are molecules that can reduce the effects of free radicals to stabilize the harmful molecules, neutralize free radicals by donating electrons, or accept it by eliminating the conditions of unpaired electrons in radicals [4]. The use of antioxidants that act as free radical scavenger is a strategy to prevent the initiation of cancer cells induced by ROS and the early stages of carcinogenesis and thus can reduce the incidence of cancer [5]. Antioxidants cause resistance to oxidative stress by reducing free radicals, inhibiting lipid peroxidation, and other mechanisms so as to prevent the disease [6].

Coleus amboinicus Lour. A plant that has been used ethnobotany in Indonesia for empirical by the people of North Sumatra, especially mothers who breastfeed. Many pharmacological properties have been reported in C. amboinicus Lour. including urolithiasis, antiepileptic, antitumorogenic, antimutagenic, radioprotective effect, antiviral, antifungal, and neuropharmacological properties [7]. Several studies of this plant have conducted a research on the antioxidant activity and cytotoxic leaf extract of $C$. amboinicus Lour. [8]. The results showed that the ethyl acetate extract and ethanol extract have antioxidant activity with $\mathrm{IC}_{50}$ values of each $350.74 \mu \mathrm{g} / \mathrm{mL}$ and $281.26 \mu \mathrm{g} / \mathrm{mL}$ with DPPH. This study aimed to assess cytoprotective effect of $C$. amboinicus Lour. in Vero cells which induced by $\mathrm{H}_{2} \mathrm{O}_{2}$.

\section{MATERIALS AND METHODS}

\section{Material}

The n-hexane, ethyl acetate, and ethanol were purchased from Merck (Darmstadt, Germany), DMSO (Merck), 3-(4,5-dimethylthiazol-2-yl)2,5-diphenyl tetrazolium bromide (MTT) (Sigma Chemical, St. Louis, MO), $\mathrm{H}_{2} \mathrm{O}_{2}$ from Merck Darmstadt, Germany, and M199 media and phosphate-buffered saline (PBS) 10\% v/v (Gibco, Grand Island, NY, USA).

\section{Plant material}

C. amboinicus Lour. was obtained from Tanjung Pura, Langkat, North Sumatera, Indonesia. The plant was identified at Herbarium Meandense, University of Sumatera Utara.

\section{Preparation of Ethanol Fraction (EtF)}

The leaves of $C$. amboinicus were dried at $45^{\circ} \mathrm{C}$ and ground into powder. The dried leaves powder ( $1 \mathrm{~kg}$ ) was extracted with $\mathrm{n}$-hexane by maceration method $(3 \times 3 \mathrm{~d}, 7.5 \mathrm{~L})$ at room temperature with occasional stirring. The same procedure was applied to ethyl acetate and ethanolic fraction. Fraction from each solvent was concentrated by a rotary evaporator (Heidolph VV-200) and the concentrated fraction was dried by freeze-dryer (Edwards).[9,10].

\section{Cytoprotective assays}

\section{MTT assays}

Cytoprotective activity was determined by the MTT colorimetric assay. Vero cell lines were plated at $1 \times 10^{4}$ cells/well in a 96-well plate was grown in M199 medium, containing 10\% fetal bovine serum (Gibco), 1\% penicillin-streptomycin (Gibco), and fungizone $0.5 \%$ (Gibco). The culture cells were incubated in a humidified incubator at $37^{\circ} \mathrm{C}$ at atmosphere of $5 \% \mathrm{CO}_{2}$ and $95 \%$ air for $24 \mathrm{~h}$. After incubation for $24 \mathrm{~h}$ at $37^{\circ} \mathrm{C}$, the medium was discharged and cells were treated by EtF with different concentrations and incubated for $24 \mathrm{~h}$. After that, cell was induced with $0.8 \mathrm{mM} \mathrm{H}_{2} \mathrm{O}_{2}$ for $3 \mathrm{~h}$. MTT $0.5 \mathrm{mg} / \mathrm{mL}$ solution was added to each well and further incubated for $4 \mathrm{~h}$ at $37^{\circ} \mathrm{C}$. Viable cells react with MTT to produce purple formazan crystals. After $4 \mathrm{~h}$, the stopper $10 \%$ SDS (Sigma) in 0.01 
$\mathrm{N} \mathrm{HCl} \mathrm{(Merck)} \mathrm{was} \mathrm{added} \mathrm{to} \mathrm{dissolve} \mathrm{the} \mathrm{formazan} \mathrm{crystal.} \mathrm{The} \mathrm{cells} \mathrm{were}$ then incubated for $24 \mathrm{~h}$ at room temperature and protected from light. After incubation, the cells were shaken. Optical density was read with an ELISA reader at $\lambda 595 \mathrm{~nm}$. The experimental data were absorbance of each well and then converted to a percentage of viable cells [11-13].

The equation to determine viability of cells is:

Viability $=\frac{\text { Absoftreatment }- \text { Absofmedium }}{\text { Absofcontrolcells-Absofmedium }} \times 100 \%$

\section{Flow cytometry analysis}

Vero cells $\left(5 \times 10^{5}\right.$ cells/well $)$ were seeded into 6-well plate and incubated for $24 \mathrm{~h}$. After that, were induced with $0.8 \mathrm{mM} \mathrm{H}_{2} \mathrm{O}_{2}$ for $3 \mathrm{~h}$. And then, the cells were treated with $\operatorname{EtF}(100 \mu \mathrm{g} / \mathrm{ml})$ and then incubated for $24 \mathrm{~h}$. Both floating and adherent cells were collected in conical tube using trypsin $0.025 \%$. The cells were washed thrice with cold PBS and centrifuged $2500 \mathrm{rpm}$ for $5 \mathrm{~min}$. The supernatant was separated, while the sediment was collected and fixed in cold $70 \%$ ethanol in PBS at $-20^{\circ} \mathrm{C}$ for $2 \mathrm{~h}$. The cells were washed thrice with cold PBS and suspended, then centrifuged $3000 \mathrm{rpm}$ for $3 \mathrm{~min}$ and annexin $V$ kit added to sediment and suspended and incubated at $37^{\circ} \mathrm{C}$ for $30 \mathrm{~min}$. The samples were analyzed using FACScan flow cytometer [11-13].

\section{Immunocytochemistry assays}

Vero cells $\left(5 \times 10^{4}\right.$ cells/well) were seeded on coverslips in 24-well plate and incubated for $24 \mathrm{~h}$. After that, Vero cell Line were induced with $0.8 \mathrm{mM} \mathrm{H} 2 \mathrm{O} 2$ for $3 \mathrm{~h}$. The cells were treated with ethanol extract and then incubated for $24 \mathrm{~h}$. After incubation, the cells were washed with PBS and then fixed with cold methanol at $4{ }^{\circ} \mathrm{C}$ for $10 \mathrm{~min}$. After that, the cells were washed with PBS and blocked in hydrogen peroxide $\left(\mathrm{H}_{2} \mathrm{O}_{2}\right)$ blocking solution for $10 \mathrm{~min}$ at room temperature, incubated using primary antibody ROS for $1 \mathrm{~h}$, then washed thrice with PBS, and then incubated with secondary antibody for $10 \mathrm{~min}$. The cells were washed with PBS, then incubated in 3,3-diaminobenzidine (DAB) solution for $10 \mathrm{~min}$, and washed with Aquadest. Afterward, the cells were counterstained with Mayer Hematoxylin for 5 min, and the coverslips were taken and washed with Aquadest and then immersed with xylol and ethanol 70\%. Protein expression observed by a light microscope (Nikon YS100). Cells that express a particular protein will provide the brown color, while the cells that do not give a specific protein will provide blue color [11].

\section{RESULT AND DISCUSSION}

MTT methods are a quantitative test. This test is based on measuring the intensity of the color (colorimetric) that occurs as a result of metabolism of a substrate by living cells into a colored product. This assay is based on the assumption that dead cells or their products do not reduce tetrazolium. The assay depends both on the number of cells present and on the mitochondrial activity per cell $[14,15]$. The reduction of yellow tetrazolium MTT is reduced by metabolically active cells, in part by the action of dehydrogenase enzymes, to generate reducing equivalents such as NADH and NADPH. The resulting intracellular purple formazan can be solubilized quantified by spectrophotometric means. The extract showed cytoprotective activities in a concentrationdependent manner (Fig. 1).

Fig. 1 shows that $\mathrm{H}_{2} \mathrm{O}_{2}$ as the oxidant source in this study at a concentration of $0.8 \mathrm{mM}$ has induced cell damage and a decrease in live cell count by $5 \%$ compared with Vero cell control without $\mathrm{H}_{2} \mathrm{O}_{2}$ treatment. The EtF of $C$. amboinicus was found to be $76.08 \pm 0.91 \%$ at $100 \mu \mathrm{g} / \mathrm{mL}$ compared with control cell with $\mathrm{H}_{2} \mathrm{O}_{2}$ treatment. These results indicate that ethanol extract has cytoprotective activity.

Evaluation of cell viability was performed using flow cytometry assay with annexin $V$ and PI as shown in Fig. 2 and Tabel 1. The percentage of cell treatment by EtF in viability cell was $49.59 \%$, in early apoptotic was
$30.32 \%$, in late apoptotic/early necrotic was $3.91 \%$, and in late necrotic was $16.27 \%$. Percentage of cell count with early apoptosis for cell control was $9.42 \%$, cell control $+\mathrm{H}_{2} \mathrm{O}_{2}$ was $10.93 \%$, and $\mathrm{EtF}$ was $30.23 \%$. Percentage of cell count with late apoptosis or early necrosis for control was $2.97 \%$, cell control $+\mathrm{H}_{2} \mathrm{O}_{2}$ was $45.72 \%$, and $\mathrm{EtF}$ was $3.91 \%$. The final apoptosis signifies that the cell has fragmented DNA and undergoes phagocytosis. Percentage of cell number late necrosis for cell control 7.04\%, cell control+ H2O2 33.03\%, and EtF 16,27\%. Decreased necrotic cells show that EtF has no cytotoxic ability. The number of viability cells on the control of cells $+\mathrm{H}_{2} \mathrm{O}_{2}$ is very small because many cells experience death from apoptosis and necrosis. Apoptosis and necrosis will increase as the percentage of viability cells decreases. $\mathrm{H}_{2} \mathrm{O}_{2}$ is a non-radical ROS with weak oxidizing activity. It diffuses through cell membranes rapidly and interacts with $\mathrm{Fe}^{2+}$ and possibly $\mathrm{Cu}^{2+}$ ions to form hydroxyl radicals and other free radicals [14].

Immunocytochemistry assay with ROS antibody is negative characterized by blue stained nuclei in the cells (Fig. 3). The results obtained that the cells can be protected by EtF, so there are few cells that express ROS. This shows that EtF has protective activity against cells that have been induced with $\mathrm{H}_{2} \mathrm{O}_{2}$ because it can decrease ROS expression.

As seen in Fig. 3, the control cell showed strongly brown positive reactions in the cell cytoplasm, many giant cells, irregular cell shape, and cell nuclei shrink, as seen in the cell control $+\mathrm{H}_{2} \mathrm{O}_{2}$. Negative reactions show blue in the cytoplasm, as shown in the cell control and ethanol extract. The results showed that the cells can be protected by ethanol extract, so there are few cells that express ROS. Thus, it is possible that ethanol extract has protective activity against cells that have been induced with $\mathrm{H}_{2} \mathrm{O}_{2}$ because it can decrease ROS expression.

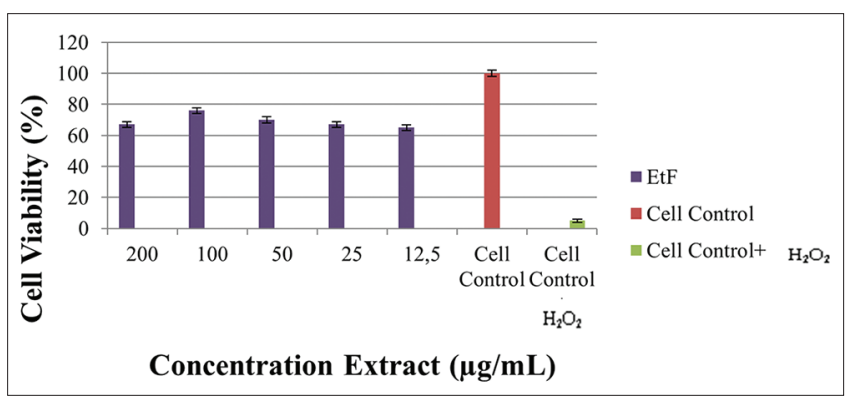

Fig. 1: Viability of ethanol fraction on 3-(4,5-dimethylthiazolyl-2)2,5-diphenyltetrazolium bromide assay

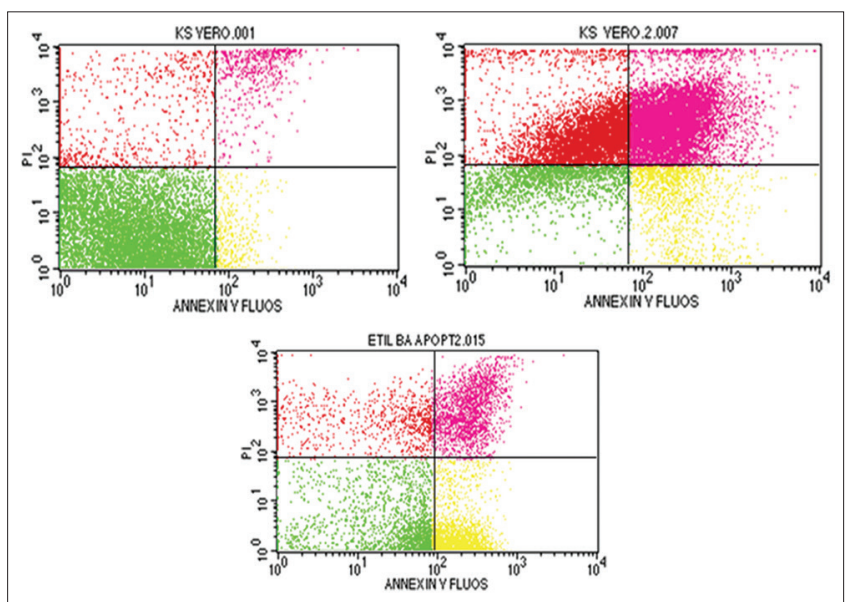

Fig. 2: Apoptotic analysis of ethanol fraction on Vero cell line. (a) control cells; (b) control cells $+\mathrm{H}_{2} \mathrm{O}_{2}$; (c) ethanol extract $(100 \mu \mathrm{g} / \mathrm{mL})$ 


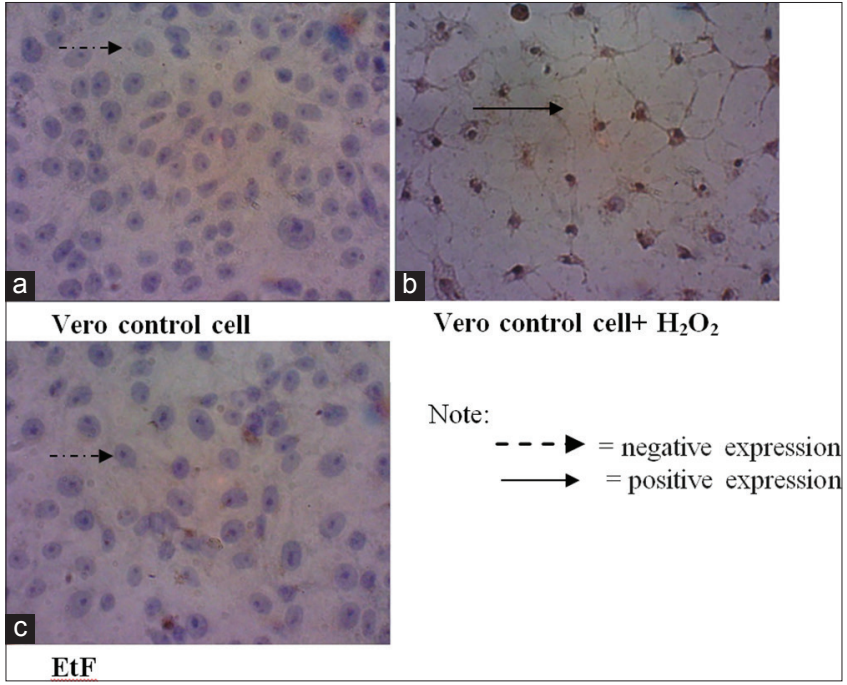

Fig. 3: Expression of radical spesies oxygen antibody with immunocytochemistry assay. (a) Vero control cell, (b) Vero control cell $+\mathrm{H}_{2} \mathrm{O}_{2}$, (c) ethanol fraction

Table 1: Evaluation of cell viability was performed using flow cytometry assay with annexin V and PI

\begin{tabular}{lllll}
\hline Treatment & LL (\%) & LR (\%) & UR (\%) & UL (\%) \\
\hline Control cells & 80.56 & 9.42 & 2.97 & 7.04 \\
Control cells $\mathrm{H}_{2} \mathrm{O}_{2}$ & 10.32 & 10.93 & 45.72 & 33.03 \\
EtF & 49.59 & 30.23 & 3.91 & 16.27 \\
\hline
\end{tabular}

LL: Lower left: The percentage of viability cells, LR: Lower right: The percentage of early apoptotic, UR: Upper right: The percentage of late apoptotic/early necrotic, UL: Upper Left: The percentage of late necrotic

C. amboinicus Lour. contains flavonoids. Flavonoids contribute to antioxidant activity in vitro by flavonoids can chelate metal ions prevent them in participation to form free radicals and protect against oxidative stress Antioxidant flavonoids seem to be a combination of direct reaction with free radicals and chelating properties responsible for the production of ROS. It is believed that antioxidants exert their protective effect by decreasing oxidative damage to DNA and by decreasing abnormal increases in cell division [16-17]. Flavonoids inhibit the enzymes responsible for superoxide anion production, such as xanthine oxidase and protein kinase $C$. A number of flavonoids efficiently chelate trace metals, which play an important role in oxygen metabolism. Free iron and copper are potential enhancers of ROS formation, as exemplified by the reduction of $\mathrm{H}_{2} \mathrm{O}_{2}$ with the generation of the highly aggressive hydroxyl radical [18].

\section{CONCLUSION}

From these result, it is concluded that the EtF of $C$. amboinicus Lour. has cytoprotective activities on injured Vero cell line. The results also indicate that plant extract is a significant source of natural antioxidant, which might be helpful in preventing oxidative stress from $\mathrm{H}_{2} \mathrm{O}_{2} 0.8 \mathrm{mM}$. EtF with MTT assay showed the viability cell by $76.08 \pm 0.91 \%$ at $100 \mu \mathrm{g} / \mathrm{mL}$, increased viability cell by flow cytometry, and decreased ROS expression with immunocytochemistry.

\section{ACKNOWLEDGMENTS}

The authors thank to support in carrying out the work. Especially to all staff of research laboratory, University of Sumatera Utara, and all staff of the Department of $t$ of Pharmacology, Pharmaceutical Chemistry, and Pharmaceutical Biology, Faculty of Phamnacy,University of Sumatera Utara

\section{CONFLICT OF INTEREST}

The authors have no any conflicts of interest in this work.

\section{REFERENCES}

1. Kurkcu R. The effects of short-term exercise on the parameters of oxidant and antioxidant system in handball players. Afr J Pharm Pharmacol 2010;4:448-52.

2. Kovacic P, Jacintho JD. Mechanisms of carcinogenesis: Focus on oxidative stress and electron tranfer. Curr Med Chem 2001;8:773-96.

3. Barr SJ, Lux CD, Mahmoud E, Almutairi A. Exploiting oxidative microenvironments in the body as triggers for drug delivery systems. Therapeutics 2016;21:730-54.

4. Lu JM, Lin PH, Yao Q, dan Chen C. Chemical and molecular mechanisms of antioxidants: Experimental approaches and model systems. J Cell Mol Med 2010;14:840-60.

5. Wolfe KL, Kang X, He X, Dong M, Zhang Q, Liu RH, et al. Cellular antioxidant activity of common fruits. J Agric Food Chem 2008;56:8418-26.

6. Ahalya B, Ravishankar K, Priyabandhavi P. Evaluation of in vitro antioxidant activity of annonamuricata bark. Int J Pharm Chem Biol Sci 2013;3:406-10.

7. Bhatt P, Negi PS. Antioxidant and antibacterial activities in the leaf extracts of Indian borage (Plectranthus amboinicus). Food Nutr Sci 2012;3:146-52.

8. Hasibuan PA, Ilyas SR, Nasution MP. Antioxidant and cytotoxic activities of Plectranthus amboinicus (Lour.) spreng. extracts. Int $\mathrm{J}$ Pharm Teach Pract 2013;4:755-8.

9. Dalimunthe A, Achmad S, Satria D. Phenolic, flavonoid content and antioxidant activities of ethylacetate extract of Litsea cubeba (Lour.) pers. barks. Pharm Chem 2016;8:466-8.

10. Sihotang Y, Silalahi J, Hadisahputra S, Anjelisa P, Satria D. Cardioprotective effect of ethylacetate extract of poguntano (Picriafelterrae Lour.) againts doxorubicin-induced cardiotoxicity in rats. Int $\mathrm{J}$ Pharm Clin Res 2016;8:466-70.

11. Anggraeni R, Hadisahputra S, Silalahi J, Satria D. Combinational effects of ethylacetate extract of Zanthoxylum acanthopodium DC. With doxorubicin on T47D breast cancer cells. Int J PharmTech Res 2014;6:2032-5.

12. Hasibuan PA, Rosidah S. Combination Effect of Ethyl acetate Extract of Plectranthus amboinicus (Lour.) spreng. With doxorubicin againts hela cell lines. Int J Pharm Clin Res 2016;8:357-60.

13. Satria D, Silalahi J, Haro G, Ilyas S, Hasibuan PA. Antioxidant and antiproliferative activities of an ethylacetate fraction of Picria fel-terrae Lour. herbs. Asian Pharm J Clin Prev 2017;18:399-403.

14. Kumar AD, Bevara GB, Laxmikoteswramma K, Malla RR. Antioxidant, cytoprotective and antiinflammatory activities of stem bark extract of semecarpus anacardium. Asian J Pharm Clin Res 2013;6:213-9.

15. Kanchana $P$, Kanchana $G$, Rubalakshmi G. In vitro anticancer activity of Hydro-alcohol extract of leaves of andrographis neesiana against Pc-3 and Mcf-7 cell lines. Int J Pharm Pharm Sci 2012;4(2):396-99.

16. Symonowicz M, Kolanek M. Flavonoids and their properties to from chelate complexes. Biotechnol Food Sci 2012;76:35-41.

17. Dey S, Roy S, Deb N, Sen KK, Besra SE. Anti-carcinogenic activity of Ruellia tuberosa L. (Acanthaceae) leaf extract on hepatoma cell line and increased superoxide dismutase activity on macrophage cell lysate. Int J Pharm Pharm Sci 2013;5(3):854-61.

18. Pietta PG. Flavonoids as antioxidants. J Nat Prod 2000;63:1035-42. 